ARTICLE

Teceived 18 Jul 2015 | Accepted 3 Sep 2015 | Published 13 Oct 2015

DOI: $10.1057 /$ palcomms.2015.30

OPEN

\title{
The monstrosity of the multitude: unredeeming radical theology
}

Karen Bray ${ }^{1}$

\begin{abstract}
If its power comes from the very value held so dear by neoliberalism-that of productivity - can the "multitude" as conceived by Michael Hardt and Antonio Negri ever fully resist the neoliberal Empire? Engaging the Autonomous Marxism of Franco "Bifo" Berardi, I argue that continued philosophical and theological emphases on productivity resonate with a soteriological narrative embedded in neoliberalism's promise that work is redemptive. As both counter and supplement to such emphases, this essay offers an alternate reading of Hardt and Negri's multitude through the lens of crip (disability) theory. In Sex and Disability crip theorists Anna Mollow and Robert McRuer argue that counter to Joseph Conrad's assertion that " 'A man is a worker. If he is not then he is nothing,' " a crip politics says, "fuck employability: I'm too sick to work" (25). To embrace the stigma of sickness is to question the demands of productive labour on offer by society. A similar crip politics, one that tells the Empire it is too sick to work and too slow to be efficient, might loose the multitude from its redeployment in the very technologies of power Hardt and Negri hope to counter. Looking to figures of monstrosity, I argue that productivist tendencies within radical theology betray the field's crip potential. Ultimately, this essay seeks to recover the multitude's monstrosity from within Hardt and Negri's corpus. A return to its monstrosity returns the multitude to its unproductive potency, that which wanders away from demands of social cohesion, and thus resists redemptive wholeness. This article is published as part of a collection dedicated to radical theologies.
\end{abstract}

\footnotetext{
${ }^{1}$ Eugene Lang College of New School University, New York, NY, USA
} 


\section{Introduction: questioning productive redemption}

n Multitude Hardt and Negri (2005: 135) argue that today,

"No social line divides productive from unproductive workers ... these distinctions ... have often been used to exclude women, the unemployed, and the poor from central political roles, entrusting the revolutionary project to the men (with calloused hands from the factories) who were thought to be the primary producers". This troubling of the productive/unproductive divide appears to be a radical rejection of a neoliberal politics of efficiency and productive particularity. And yet, in their continued emphasis on the productivity of the multitude Hardt and Negri betray this radical rupture. If the line no longer stands, why not look to the multitude's unproductivity? What types of inscriptional violence does embracing the value of productivity commit? What does productivity as the site of the collectivization of subjectivity for the empowerment of the multitude say to those subjects who refuse their productive capacities? In other words if the power of and commonality between the multitude come from the very value held so dear by the Empire-that of productivitycan the multitude effectively counter neoliberalism? By looking to Multitude and its theological deployment in Rieger and Kwok's (2012) Occupy Religion: Theology of the Multitude this essay attempts an answer and offers an alternate reading of work through the Autonomism ${ }^{1}$ of Franco "Bifo" Berardi and a crip theology of value constructed out of poetics and experiences of disability.

Continued philosophical and theological emphases on the productivity of the multitude resonate with a salvific narrative embedded in neoliberalism's understanding of work as redemptive. Would rethinking work, not simply to reorient where we place our resources and assign our values but also to nurture a refusal of productivity, better disentangle our acts of resistance from narratives of redemption? In response to this question this essay proposes a politic, poetic and theology of unproductivity. Berardi's examination of the affectual effects of what he calls SemioCapitalism ${ }^{2}$ in The Soul at Work (2009) along with his post-futurist proposals in After the Future (2011) will serve as an alternate reading of productivity. Ultimately, however, it is Hardt and Negri's turn to the monstrosity of the multitude, read anew through crip theory ${ }^{3}$ and a poetics of disability, that opens us to how this unproductive stance might be embodied in a crip theology of worth divorced from efficient production. Through reading Hardt and Negri's monstrous multitude with a crip sensibility, I seek out a theology that resists productivity as a method of salvation, and thus troubles the concepts of redemption on offer by both neoliberalism and theologies hoping to counter its deleterious effects.

\section{The productivity of the multitude}

In Occupy Religion: Theology of the Multitude, Rieger and Kwok (2012: 67) draw on Paul's epistles to discuss the importance of the multitude's common productivity: "The eye cannot say to the hand, 'I have no need of you,' nor again the head to the feet, 'I have no need of you.' On the contrary, the members of the body that seem to be weaker are indispensible, and those members of the body that we think less honorable we cloth with greater honor, and our less respectable members are treated with greater respect (1Cor. 12:21-24)". According to Rieger and Kwok, the productivity of the multitude honours the contributions to the social body made by those considered inferior. For Hardt and Negri the multitude's ability to resist the capitalist empire stems from the fact that even those who we normally assume to be outside the traditional labour economy are part of social production. That all classes produce in common allows them to resist in common-common productivity as bond. But what of the blind woman who does not need the eye or the amputee who does not need the hand? What of those cut off or breaking away from the community that is the social body? Is the focus on common productivity too eerily resonate with a soteriological structure embedded in neoliberalism that ties our worth to our work-who we are to what we can do for one another? Rieger and Kwok continue:

The multitude picks up the concerns of working people, the so-called working class, because it values the notion of production. While the multitude is forced to endure the pressures of the system, it does not remain passive. Working people make substantial contributions to society, which are often overlooked and underappreciated. Hardt and Negri extend the multitude to the unemployed, unpaid domestic laborers, and the poor, who also make substantial contributions to society. We agree with their idea that 'the multitude gives the concept of the proletariat its fullest definition as all those who labor and produce under the rule of capital' [10]. (Rieger and Kwok, 2012: 61)

While, as Rieger and Kwok make clear, Hardt and Negri include the unemployed and underpaid in their definition of the productive multitude, that political emphasis remains on production and societal contribution is problematic. To be sure, the dismantling of what we can recognize as the "We Built This" notion made famous by Mitt Romney's 2012 presidential bid is key for the work of solidarity sought by Rieger and Kwok. Members of the $1 \%$ rallied behind the notion that those in the lower classes owed our livelihoods to those at the top, to the wealth the rich claimed to have built and then benevolently shared with the rest of us. An emphasis on the productivity of the multitude resists this narrative, helpfully bringing to the fore the ways in which wealth relies on the work of the impoverished. Yet, the ways in which the productivity of the multitude not only built the wealth of the $1 \%$ but also sustain that wealth are obscured by Rieger and Kwok's productivism. Hence, the attempt to regain the worthiness of the multitude through what we have done for an economic system that continues to betray us is at best rash and at worst a tightening of the chains that bind us to an exploitative market. If we are to regain power through a reassertion of our worth in directed activity, then we have not unbound ourselves from the tragic narrative that it is what we can do for the system rather than who we are-our singular ${ }^{4}$ embodied desires and becomings-that defines our worth. Indeed a focus on labour continues to allow the terms of worth to remain within a theological system fortified by, and which fortifies, a productivist ethic summed up in Joseph Conrad's proposal (critiqued by crip theorists Anna Mollow and Robert McRuer) that "a man is a worker. If he is not then he is nothing" (McRuer and Mollow, 2012: 25). The addition of the unemployed and underpaid domestic worker to the definition of the multitude does not refute Conrad's proposition; rather it affirms that regardless of our employment status we all are indeed workers. Instead of a radical refutation of the need to be a worker to be of worth, a productivist theology in the form proposed by Rieger and Kwok borders on apologetics-a theology begging for the recognition of the impoverished as societal contributors. The terms of value remain intact. Rieger and Kwok (2012: 62) continue, "Hardt and Negri focus on economic class, in part because this concept has not received enough attention in recent debates, but also because the multitude needs to be understood in terms of economic production. It is both the 'common subject of labor, that is, the real flesh of postmodern production' and 'the object from which collective capital tries to make the body of its global development'". The focus on class can help us to raise issues of 
fair wages and just labour practices. And yet from a theological point of view, Rieger and Kwok's proposals often obscure the problem of where we place ultimate value, focusing instead on how that value gets determined, measured and compensated.

Rieger and Kwok (2012: 100) admit that if one is going to follow the teachings of Jesus one cannot "serve two masters" and hence cannot serve both God and wealth. Yet, in using the gospels to theologically valorize agency and productivity (which may not be able to escape the fact that today demands to be productive are injunctions to worship the promise of money) their theology is undermined. They note that "Jesus's healings tend to encourage agency and productivity as well. He responds to a man who has been waiting for help for thirty-eight years with these words: 'Stand up, take your mat and walk' (John 5:8)" (Rieger and Kwok, 2012: 71) and that "[Jesus spent time healing] the paralyzed, whose agency had been shattered, and the possessed whose personalities had been destroyed. He combated religious neuroses by proclaiming the forgiveness of God and put people back on the road: 'Stand up and take your bed and walk' (Mark 2:9) and 'Get up!' (Mark 5:41)” (Rieger and Kwok, 2012: 86). Theirs is a theology in which, "In short, discipleship means becoming a productive agent in relationship with other productive agents" (Rieger and Kwok, 2012: 73). The demand to take your mat and walk resonates with a neo liberal demand to get to work. Might the demand to "Get up!" resonate with "Stop being so lazy!"? What about the agency of the paralyzed as paralyzed? Or that of the shattered as shattered and the neurotic as neurotic? What of those too sick to work? Too tired to participate? Too isolated to contribute? Too wilful to attune to the demands of other productive agents? ${ }^{5}$ Must we adjust to the call for productivity, or might we learn from unproductivity? Which stance better counters neo liberal constructions of value?

\section{Soulfully unproductive}

While similarly drawing on (both to embrace and move beyond) the work of Antonio Negri as well as the radical thought of others in the 1960s and 1970s Italian Workerist (Operaismo), Autonomist and Compositionist movements, Franco "Bifo" Berardi resists a rhetoric of productivism and questions the political potency of the concept of the multitude. In both The Soul at Work and After the Future, Berardi explores the affectual effects of post-Fordist modes of production and communication (SemioCapitalism) on our individual and social psyches. In doing so he not only diagnoses the toxic effects of neoliberalism, but also elaborates a politics and poetics of the refusal of work. The unproductivity on offer by Berardi exposes the affectual and ethical issues raised when we remain within the logic of productivism, even that which claims a revolutionary and counter-imperial stance. According to Berardi (2009: 21), SemioCapitalism "takes the mind, language and creativity as its primary tools for the production of value". Under SemioCapitalism the soul is not left out of work, but rather becomes the very mode of production and thus the tool of its own estrangement. Hence, while the resistance to alienation through the reassertion of the importance of one's mind and soul was at the heart of organizing workers on the factory floor, under postFordism acts of resistance must take on a different character. The goal of autonomy or what Berardi rewrites as out-onomy becomes not how to overcome alienation, but rather how to increase the estrangement between the soul and capitalist labour relations. As Berardi notes:

The working class is no longer conceived as a passive object of alienation, but instead as the active subject of a refusal capable of building a community starting out from its estrangement from the interests of capitalistic society ... Alienation is then considered not as the loss of human authenticity, but as estrangement from capitalistic interest, and therefore as a necessary condition for the construction-in a space estranged from and hostile to labor relations-of an ultimately human relationship. (Berardi, 2009: 23)

To become increasingly estranged from labour relations involves for Berardi a multistep process: first, we must understand the way in which SemioCapitalism has redefined value; second, we must identify the affectual effects of SemioCapitalism on our individual and social psyches (effects that Berardi names as exhaustion and depression in After the Future and the panicdepression cycle in The Soul at Work); and third we must engage Deleuze and Guattari's schizoanalysis as a political therapy that helps us to reorient the field of desire and thus reframes the concept of wealth, re-engaging us in authentic human relationships. Each of these steps happens not through reasserting our productive capacity, but rather through refusing to participate in the systems of production on offer by SemioCapitalism's labour relations.

Under SemioCapitalism value has been divorced from all referent points. When Richard Nixon cancelled the direct convertibility of the US dollar to gold the referential logic of value was discarded in favour of what Berardi (2009: 148) calls "generalized indeterminacy". From a radical theological point of view a sense of generalized indeterminacy may sound ideal in that, like radical theology, it denies a determinate telos. It might resonate, for instance, with Robbins's call for a radical democratic resistance to all forms of hegemony that will come by way of an immanent exodus, one that, Robbins notes quoting Negri, is an "exodus from obedience, that is to say, from participation in measure, i.e., as the opening to the immeasurable" (Robbins, 2013: 191). Or it might resonate with the indefinite or infinite eschatology proposed by Crockett (2011: 102). Yet as Berardi notes, the indeterminacy of value and the process of economic deregulation brought on by SemioCapitalism did not result in anarchic freedom. It remains tamed and obedient to a certain eschatological vision: "Deregulation does not mean that society is freed from all rules, not at all: it is instead the imposition of monetary rule on all domains of human action. And monetary rules are in fact the sign of a relationship based on power, violence and military abuse" (Berardi, 2009: 148). In other words, as Philip Goodchild (2009: 188) has noted, neoliberal deregulation has trapped us in the eschatological shadow of money, within which spending time is subordinated to saving it. While this eschatological promise may be indeterminate because money no longer refers to a stable referent, it serves not as a source of freedom, but rather as one of entrapment. To counter this mode of violent entrapment Berardi (2009: 140) redefines wealth as time (or in Goodchild's framing, spending time): "time for pleasure and enjoyment", which includes time to travel, learn and make love. This wealthy time is not a time that asks, "What have you done for me lately?" Rather it is unproductive time, it is a time to be lazy, to be pleasured, to just be. It is not discipleship in action; it is not worth in productivity; it is not a man who is a worker or nothing at all; rather, it is a soul who is wealthy because she is much more and much less than her labour. To be sure, there is political work to be done to democratize the availability of this wealth of time, ${ }^{6}$ but by reorienting wealth and worth away from work, indeed in finding it in the refusal of work, Berardi rejects hegemonic structures of value.

Both SemioCapitalism's rejection of wealth as time and its degradation of unproductive time lead to a mental and soulful breakdown in individual and social psyches. Berardi diagnoses this breakdown as a panic-depressive cycle (Berardi, 2009) and exhaustion and depression (Berardi, 2011). 
Acknowledging Baudrillard's prescience, Berardi (2009: 179) further notes that "The dominant pathology of the future will not be produced by repression, but instead by the injunction to express, which will become a generalized obligation". The constant demands to be expressive and productive combined with the overwhelming flow of information and signs without stable referents lead to panic, which eventually leads to depression. Elsewhere, Berardi (2011: 135-138) marks the panic-depression cycle with Baudrillard's concept of exhaustion. Exhaustion sets in because, "In semiocapitalist hyperreality, the brain is the market. And the brain is not limitless, the brain cannot accelerate indefinitely" (Berardi, 2011: 136). Rather than, or perhaps as both counter and supplement to, an emphasis on the plasticity of the brain (an emphasis embraced by followers of Catherine Malabou), ${ }^{7}$ Berardi asks us to look to the limits of the brain-to our exhaustion - for the rethinking of how we might come to be differently.

The depression and exhaustion-markers of the limit of the brain (or perhaps better, the "bodymind" 8 ) - that follow the panic induced by our overstimulation can be traced back to the demands for the brain to accelerate indefinitely. In other words, "the constant mobilization of attention is essential to the productive function: the energies engaged by the productive system are essentially creative, affective and communicational" (Berardi, 2011: 107). Rather than rejecting the need for creative and affective communication or for action writ large, Berardithrough his diagnosis of the overstimulation of the brainilluminates how the demand to be productive and expressive pushes the individual and collective psyche to their breaking points. He writes, "Not silence, but uninterrupted noise, not Antonioni's red desert, but a cognitive space overloaded with nervous incentives to act: this is the alienation of our times" (Berardi, 2011: 108). We might say that "our times" takes on a double meaning in this case, as it is the very demand for more of our time that defines the nature of the Time of Neoliberalism or, in Berardi's terms, SemioCapitalism.

This is not to uphold an utter dulling of the mind, but rather an injunction to seek out new ways of thinking and feeling ourselves through the affectual experiences of the bodymind under such temporal demands. For instance, the chaotic hyperactivity of indeterminate signs that often engenders depression can also contain a sense of creative ecstasy: "The world-chaos that Guattari talks about in his last book is not only depression, fog, and miasma. Chaos is much more than this. It's also the infinity of colors, dazzling lights, hyperspeed intuitions, and breathtaking emotions. (Deleuze and Guattari, 1994, 203)" (Berardi, 2011: $160)$. In this way, a turn towards our exhaustion or depression need not be the silencing of the sounds of indeterminacy and chaos, but rather a slowing down to the point where we take pleasure in the cacophony of singularities; when exhausted we would grant ourselves permission to fall back into bed and just listen. No longer trying to harmonize sounds that will not or will to not come together, we might clear a path to see what can happen on the other side of exhaustion when we are not fuelled by the panicked desire to numb our depression. For this fall into bed, the being exhausted, need not be a passive nihilism. Rather, feeling ourselves to be backwards in a society that says we must move forward resonates with the backward feelings of being queer as explicated by Heather Love. Love (2007: 1) notes that backward feelings are "all about action: about how and why it is blocked, and about how to locate motives for political action when none is visible". In other words, a turn not towards the productivity of the multitude but rather towards its depressing exhaustion might uncover invisible political possibilities.

The slowness and quotidian nature of depressing passive-acts like the fall into bed, or the listening for the sounds of chaotic miasma and those of the infinity of colours, further troubles a productivist politics found within the work of Rieger and Kwok, Hardt and Negri, and much of radical theology. For instance, we can locate within the field of radical theology (or of theologies and philosophies arising in the wake of the "Death of God") a problematic emphasis on action. Whether it takes the form of multitudinous productivism, event, exodus, messianism or revolution, ${ }^{9}$ none of these concepts (no matter how immanent their theological constructions may be) escape a sense of directional movement and change, a sense that often rings as eruptive and/or rapid. This sort of revolving (one that risks its own version of a teleological fantasy) is reflected in leftist movements nostalgic for the time of labour uprisings. ${ }^{10}$ As Shaviro (2015: 5-6) has noted, "Given the failure of economism, many Marxists have instead gone to the opposite extreme: they have embraced a kind of voluntarism. Capitalism can be abolished by sheer force of will-as long as this is supplemented by proper methods of organization and mobilization. We see this sort of approach in the Leninist doctrine of the vanguard party, and also, I think, in the ultraleftism of such contemporary thinkers as Slavoj Žižek and Alain Badiou". Shaviro (2015: 6) continues, "We cannot wait for capitalism to transform on its own, but we also cannot hope to progress by appealing to some radical Outside or by fashioning ourselves as militants faithful to some 'event' that (as Badiou has it) would mark a radical and complete break with the given 'situation' of capitalism". While Shaviro counters the Badiouian/Žižekian eventive-revolution with accelerationism, ${ }^{11}$ Berardi counters with radical passivity. Instead of viewing exhaustion as the inability to escape capitalism, the position of radial passivity acknowledges exhaustion's capability to clear a way towards an autonomous collectivity (Berardi, 2011: 138). ${ }^{12}$ Might the slow-down of exhaustion serve as a radical opening for radical thought? In other words, can radical theology embrace its own depression?

To counter the radicality of the event we may need to look to the radicality of the everyday. We may need to seek out a slowness performed in quotidian acts of refusal. For instance, instead of waiting for the revolution we might wander towards ways of slow living proposed by Lauren Berlant in her counter to "slow death". Berlant (2011: 95) defines slow death as "the physical wearing out of a population in a way that points to its deterioration as a defining condition of its experience and historical existence". Slow death might come in the form of the panic-depressive cycle, a crash from the overstimulation of the brain, or as Berlant traces it, in the wearing down of bodies through excessive food consumption, which she ties not only to exploitative food and labour policies, but also to the exhaustion of work and the search for momentary pleasure in food (Berlant, 2011, Chapter 3). This is a slow death made worse by the glorification of health and ability, states easier to achieve if one is privileged to have the wealth of time to spend on the cultivation of such abilities. As a counter to slow death, Berlant (2011, Chapter 3, footnote 64: 276) offers the possibility of counterexploitative activities, those that are anarchist, cooperative and radically antiwork. Examples of such activities might be found in the European "slow food" movement briefly touched on by Berlant. Slow food marks a movement in which practices of food cultivation, preparation and consumption "[recalibrate] the pacing of the day into a collective program for deliberative being in the world in a way opposed to the immediatist productive one of anxious capital" (Berlant, 2011, Chapter 3, footnote 64: 276). Berardi similarly offers counter-exploitative practices through the slow life of a "relaxed soul" (Berardi, 2011: 148): "Rather than a swift change in the social landscape, we should expect the slow surfacing of new trends: communities abandoning the field of the crumbling economies, more and more individuals giving up their search for a job and creating their own networks of services" (Berardi, 2011: 152). These quotidian microtactics will take time, 
but if time is wealth then perhaps slowing time down is a way of honouring the holiness of life.

This slow-down will not be easy. Berardi offers a mode in which politics and therapy are no longer separate. He asks us to learn to better take care of those made depressed and anxious by what he names as the "post-growth" economy (Berardi, 2011: 153-154). But who will lead the way? Who are we that are too anxious and on whom are we placing the therapeutic responsibility? Who gets to decide which type of depression is being exhibited-the exhaustion that leads to a slow movement towards a new civilization, or that of those made hopeless by the coming of such a civilization? Berardi (2011: 163) proposes that "Poetry and therapy (thera-poetry) will be the forces leading to the creation of a cognitarian self-consciousness: not a political party, not the organization of interests, but the reactivation of the cognitarian sensibility". How will we be able to question this reactivation? What if, like the productivism both Berardi and I hope to counter, it becomes too directed? What if it slides further into the thera-that which seeks to comfort-over the poetry-that which seeks to complicate? Perhaps, moving from the realm of the speculative into the embodied life of those already living slowly-already refusing productivity and efficiently; those living in the interstices between flesh and body; those we have marked as monstrous-will help us to seek out more poetry than therapy. More complication than comfort.

\section{Cripping cure}

What would it mean to embody an unproductive monstrosity? Re-reading the productivity of the multitude through a crip sensibility helps us to unpack this question. Crip theory is a version of disability theory that rejects assimilationist politics and apologetics. To be crip is to be unwilling to come back together as part of a productive whole. It is to refuse to wear the prosthesis so that the non-crip need not rethink the wholeness of her body. It is to refuse the cochlear implant such that mainstream society might rethink what communication looks and sounds like. It is to learn to live differently from within exhaustion and depression and not only to medicate them. According to crip theorists McRuer and Mollow (2012: 32), a crip politics says, "Fuck employability: I'm too sick to work". To embrace the stigma of sickness is to question the demands of productive labour on offer by society. Hence, a similar crip politics, one that tells the Empire it is too sick to work and that it is too depressed to produce, might loose the multitude from its redeployment in the very technologies of power it hopes to resist. In other words, to say fuck employability might also be to say fuck productivity, as long as productivity too easily slips into redemption.

As McRuer and Mollow (2012: 31) note, many disability studies projects "often [emphasize] the project of securing places for disabled people within what Deborah A. Stone calls the 'workbased system' (21), rather than challenging the structure of that system itself". Hence, similar to the apologetics risked by Rieger and Kwok's reading of the multitude, access-based disability studies often seek to return a sense of productivity to the disabled. Crippness on the other hand refuses to apologize, and rejects recognition by the systems that have betrayed us.

Therefore, to say fuck employability: I'm too sick to work might be to embrace a poetics of refusal on offer by Berardi's outonomy. For instance, in Crip Theory: Cultural Signs of Queerness and Disability (2006) McRuer exegetes Gary in Your Pocket: Stories and Notebooks of Gary Fisher, the collection of Gary Fisher's work published by his former teacher Eve Kosofsky Sedgwick 3 years after his death from HIV/AIDS. Fisher identified himself as a "black, queer, sociopath" (McRuer, 2006: 104). In this work Fisher's identities as queer, sociopathic and black destabilize one another as well as compulsory heterosexuality and able-bodiedness. This destabilization is found in what McRuer names as Fisher's non-compliance with demands for rehabilitation and redemption. Fisher's acts of noncompliance included sadomasochistic, often anonymous, sex, which included fantasies of racial degradation, and his frequent refusal to take his medication. In rejecting secur(e)ity and salvific health Fisher refused the system that had always already marked him as crip: as an untouchable monster. These acts of refusal performed a political stance of autonomy within Fisher's everyday life. They are not eventive revolutionary acts, but rather the wealthy embodiments of time by a man rejecting the pressures to be sane, able and healthy. Fisher's crip sensibility, while bringing on death more quickly, honoured the time of life through his refusal to be redeemed.

One might locate similar acts of non-compliance in the work of poet Janet Miles (whom Susan Schweik names as a poet writing in part through the lens of disability). Miles refused to be marked as disabled. In her discussion of Miles's life and work in the edited volume Beauty is a Verb: The New Poetics of Disability (2011), Schweik draws on Henri-Jacques Stiker's 1999 History of Disability to illuminate the importance of such acts of refusal:

The 'thing' has been designated, defined, framed. Now it has to be scrutinized, pinpointed, dealt with. People with "it" make up a marked group, a social entity ... The disabled, henceforth of all kinds, are established as a category to be reintegrated and thus to be rehabilitated. Paradoxically, they are designated in order to be made to disappear, they are spoken in order to be silenced. (Schweik, 2011: 70)

Like (and as one of) the "mad" figures traced by Michel Foucault in History of Madness (2006) and the figure of the "homosexual" traced in History of Sexuality I (1978), the disabled are named to either be saved out of disability (like the worker recognized as productive) or confined and silenced. Stiker's call in response to such confinement is to refuse the categories on offer. Fisher's non-compliance is similar, but instead of refusing to be marked he embraces the stigma carried by the mark sociopathic. By refusing to be named as redeemable Fisher wilfully goes unredeemed. This is the sensibility of the crip who embraces "the cripple" and thus cannot be made straight. The term "disabled" (the term as deployed by disability projects critiqued by McRuer, Stiker and Schweik) marks those whom we work to fix, and in fixing reassemble back into an efficient economy of production. But what of she who chooses to stay bent? Like the mad who plague society and hence need to be tamed, the wilfully bent take on a monstrous character.

\section{The monstrous multitude}

While it would be crucial to critique the issue of productivity within a theology of the multitude regardless of its deployment by Hardt and Negri, in turning back to the original we are better able to uncover some crip complexities. Hardt and Negri highlight the autonomy of the multitude from the Empire. If the Empire relies on the multitude to produce its wealth, then to refuse to be productive is to refuse to contribute to the wealth of the Empire. As Hardt and Negri (2005: 332) note, "Capital, in other words, must exploit the labor of workers but it cannot oppress, repress, or exclude them. It cannot do without their productivity". They continue, "[The multitude] are, in fact, extremely powerful, because they are the source of wealth" (Hardt and Negri, 2005: 333). This emphasis on the productivity of the multitude opens pathways for the radical passivity proposed by Berardi. Instead of asserting that our faith traditions have been built on action, and 
honouring the demand that the "invalid" in John stand up, take his mat and walk, to locate the potency of the multitude in its unproductivity is to ask why the man was sitting in the first place and for whom and what he would be walking.

It is this power that is recognized by Hardt and Negri when they write:

If sovereign power were an autonomous substance, then the refusal, subtraction, or exodus of the subordinated would only be an aid to the sovereign: they cannot cause problems who are not present. Since sovereign power is not autonomous, since sovereignty is a relationship, then such acts of refusal are indeed a real threat. Without the active participation of the subordinated, sovereignty crumbles. (Hardt and Negri, 2005: 332)

Given the multitude's ability to make sovereignty crumble, why not focus on the unproductive side of the line that has been dismantled between productivity and unproductivity? Perhaps we worry that such a focus will lead the multitude into inertia and despair. Perhaps this is why Žižek's (2006) own politics of refusal quickly move to a call for a Badiouian event and the revolutionary power of those in the urban slums. And yet, this multitudinous refusal need not be that of revolutionary or eventive action. Rather, we might find a poetics of refusal within the bodies of the monstrous crip who in her everyday incapacities to productively come together with the whole declares along with Berardi "that the splendor of the world has been enriched by a new beauty: the beauty of autonomy. Each to her own rhythm; nobody should be constrained to march at a uniform pace" (Berardi, 2011: 165).

Can we find the beauty of this dis-unified pace in Hardt and Negri's multitude? Perhaps it is there when they name the multitude a flesh that is not a body (Hardt and Negri, 2005: 192). Whereas Rieger and Kwok seem to focus on the potential unity of the social body, Hardt and Negri are concerned with the uncontainability of the social flesh. As not body, they argue, the flesh can often appear monstrous (Hardt and Negri, 2005: 190195). In an essay in A Conversation on Philosophy in Praise of the Common and Politics, which follows the published conversation between Cesare Casarino and Negri, Negri traces how Power ${ }^{13}$ has historically been tied to eugenics, the establishment of those who are "beautiful and good" over and above those who threaten that good, those whom we name as monstrous (Casarino and Negri, 2008: 194). According to Negri, "[labor] becomes class by recognizing itself as monster. A monstrous subject that produces monstrous resistances. The existence of class is no longer spectral but monstrous-even better, such is its essence, which carries the inscription of the force that refuses capital's productive labor" (Casarino and Negri, 2008: 199). The monster is monstrous in its refusal of capitalist productivity. Negri develops the monster further as the "autonomy of the multitude" that which "shattered the eugenic teleology", and that which "produces the common", but also that which might be captured once again either in its return to its historic function in a eugenic economy as the site of alterity from which the "beautiful and good" are birthed, or through the techniques of the biopolitical which monstrously "improves" the monster's functioning, saving him and so returning him to the productive labour of capitalism (Casarino and Negri, 2008: 200-218). Yes! An autonomous monster who refuses productivity and capture! I am even willing to abide the return of the language of the event when Negri writes:

Therefore, today is the moment to verify whether dialectics has truly ended; whether, consequently, the monster (as hegemon, through resistance of the class of those who work and are exploited) can triumph; whether the proletarian class can oppose, really, as monster, the masters' eugenic Power, kaloi kai agatoi. We say: long live the monster! Long live his capacity to dissolve any idea or project of capitalist development and of order (both old and new) that organizes it! ... Today the monster is the event waited for ... neither miscarriage nor wreckage ... even though it could be such ... but it's not! (Casarino and Negri, 2008: 203)

Indeed it is this sense of the multitude's monstrosity that must be reclaimed and reread through a crip sensibility. And yet, uneasiness remains.

In Multitude Hardt and Negri locate the monstrosity of the multitude in the figure of the vampire. The vampire is unruly; its desire for flesh (of all genders) is insatiable. It produces outside of the heteronormative family and outside of sexual reproduction all together. It creates new forms of family and sociability. The vampire marks how we must all come to recognize our monstrosity, our monstrous capabilities for imagining new forms of being assembled. And yet, the vampire's desire turns the subjects of its desires into other vampires: it is the making of one, an atonement-sameness over difference. All too quickly Hardt and Negri turn this monstrosity into a marker of the fullness of life lived in common, and thus return us to a redemptive narrative too evocative of neoliberal soteriologies. I seek not to reject life or commonality out of hand, but rather to push Hardt and Negri to be ever-more monstrous. Indeed, we might wonder just how monstrous one can be if one's monstrosity begins to mimic the monstrosity of all the other monsters. For vampires (re)productivity is replication. What if instead we looked to Frankenstein's monster who disappears into a frozen wasteland to the North, embodying a monstrous impediment to social cohesion? Or to the disembodied hands from a slew of horror movies, hands that counter to Paul do not need eyes to see? This monstrous handness creeps away from demands for productivity and wholeness. This sort of crip monstrosity, a monstrosity unable or unwilling to cohere, might enflesh an alternate radical theology, one in which we need not be redeemed through our common productivity.

Instead of the vampire who overproduces through overdesiring, Frankenstein's monster and the horrific hand turn out to be unproductive; they are impediments to cohesion and communication. They say, "Fuck reproductivity I'm just a hand!" and "Fuck employability I'm too monstrous to work!" To reclaim that level of monstrosity within the multitude would perhaps better serve Hardt and Negri's (2005: 196) assertion that "We need to use the monstrous expressions of the multitude to challenge the mutations of artificial life transformed into commodities, the capitalist power to put up for sale the metamorphoses of nature, the new eugenics that support the ruling power. The new world of monsters is where humanity has to grasp its future". But what if Berardi is right when he declares in his post-futurist manifesto that the future is an illusion we must abandon to live in the infinity of the present (Berardi, 2011: 166)?

Additionally, what of slowness? Of the everyday? Can the eventiveness of Frankenstein's monster coming alive, the disembodied hand killing its able-bodied prey, and the monster as event contain the kind of slow living that will help us to counter the overemphasis in both SemioCapitalism and radical theology on movement, productivity and revolutionary change? What other crip monsters might be lurking in the shadows waiting for us, hoping we might finally come to recognize their singularity and through them possibilities for our own monstrously unproductive lives? 


\section{The monster that therefore I am follows me}

In her "Dramatic Monologue in the Speaker's Own Voice" poet Vassar Miller, who spent her life in a wheelchair (a result of cerebral palsy), writes:

\section{I'm either a monster}

in search of a horror movie to be in, or else I'm a brain floating within a body

whose sides I must gingerly touch while you glance discreetly away ...

I wish you'd learn better before we all totter into our coffins where there's no straight way to lie crooked. (Alexander Essbaum, 2011: 50)

Might It Follows, written and directed by David Robert Mitchell and released in 2015 be the horror film of which Miller was in search? Can we read the it that does the following in It Follows as that figure of the monstrosity of the multitude that might both embody a radical slowness and diagnose the anxiety nurtured by a eugenic economy?

In the film the blond, thin, cisgendered, able-bodied teenage protagonist Jay Height "contracts" a "following it" through sexual intercourse with her boyfriend Hugh. The it that follows is singular, only following one person at a time (although others who have been followed can still recognize it). It appears in human form and can look like anyone, including one's loved ones. To make sure Jay understands that she is now being followed by it Hugh drugs Jay and ties her into a wheelchair from where she will have to face $i t$; incapacitation seems to be the only way one will fully grasp that it is coming for her. In other words, perhaps we do not see the incapacitation that hovers all around us until we feel the limitation of our mobility. Hugh goes on to tell Jay that she should never be anywhere without at least two exits because it is slow, but not dumb. Indeed the viewer quickly realizes that we can spot it even within a crowd because of how slowly it moves. Like the "cripple" who cannot rush up the subway steps, whose slowness blocks our paths on crowded city streets, it is identifiable through its speed (or lack thereof). And yet even though it is slow, one cannot escape. It is always following Jay. The it in It Follows behaves like our collective fear of disability and unproductivity, the spectre that follows us around and is amplified in a culture bent on escaping from such a haunting.

This desire to escape remains palpable even/especially as it follows us home. Home and homey places are the key staging ground for most of the action in the film. Jay is trapped in her bedroom by her fear even after she has passed it on to her friend Greg (who, believing he will not be infected/affected by it, sleeps with Jay). When it does eventually follow and then kill Greg, it appears as his mother and does so at his bedroom door. Additionally, the climactic battle with it takes place at the site of Jay's first kiss (a space of innocence in contrast to the wildness of the woods, the site of Jay's infection [through sleeping with Hugh]). It-our depression, exhaustion, panic and incapacitation - follows us home because the pressures of SemioCapitalism and neoliberalism do. Everyday depression (and the many worldly worries that nurture it and which it nurtures) follows one home, breaking down the duality between domestic and public life. Hence, in these scenes of hominess we find not only depression, but also our anxious attachments to relations that might infect us. Greg is killed by what appears to be his own mother. Despite his assumptions of untouchability, his handsome masculinity and youth do not protect him from the attack of ageing and perhaps genetic inheritance we might see represented in the appearance of his mother, an appearance it takes on at the moment of Greg's death.
Furthermore, the sexual nature of contagion in It Follows begs for a crip reading. Panic over sexually transmitted infections (STIs) - the designation of sexual Others as a plague on the "normal" and healthy, which enlivened decades of homophobia and queer politics-resonates with the disgust and panic induced by the creep of the slowness of disability. Disability as contagion. Before Miller voices her search for a horror movie, "Dramatic Monologue in the Speaker's Own Voice" reads:

I walk naked under my clothes like anyone else, And I'm not a bomb to explode in your hands.

Of course, you are not (I would not accuse you of)

Thinking of holding me down, but of holding me up.

Yet sometimes I'd love to be eased from the envelope of sleep,

Stroked gently open (although it would take some doingon my part, that is). My lost virginity

would hurt me the way ghosts of their limbs

make amputees shriek, my womanhood

too seldom used. Have you ever viewed me this way?

No, none of you ever have ... (Alexander Essbaum, 2011: 50)

We have made of those with disability, like those with STIs, untouchables. Either too sexed or too desexed, the disabled are no longer or never were for stroking gently open. The crip may not be held down, but being held up is still not being desired. If ever viewed as desirable, and as Miller makes clear that is a big if, they are now bombs ready to explode in our hands. Careful it might catch you, or worse you might catch it. Tick tick ... boom. We panic, we flee, we fear, to the point of depression, that we will be caught by the bomb of undesirability, unproductivity and hence unmeaning-in essence, inexistence.

Attempts to flee this fate pervade It Follows (what would a horror movie be without a young girl running for her life?). Through modes of speedy mobility, like a car, Jay can get away for a brief time, but eventually it will always find her/us. Is this not the function of disability in a society that demands ever-more rapidity? Like the driver of a car that cannot escape a breakdown in a crash, our bodyminds pushed to the breaking point crash into depression-into disability. Indeed, like the depressive crash that comes from the demands on the bodymind to be ever more expressive, when Jay flees a place where it has attacked she crashes her car and ends up in the hospital with a broken arm. Becoming herself broken, she is slowed down and driven mad by her desperate attempts to escape what follows.

Slowness and immobility is that which always follows; the disabled embody the one marginalized group that we are always already on the brink of becoming. The true horror embodied by it might just be, therefore, its slowness. We run, panic, crash just so as not to be caught by an infecting immobility, one that will mean the death of our capable, productive and efficient selves. And indeed, in the film if one is caught by it one dies. And at least in the opening death it is a death that is also a cripping. The film begins with a young beautiful girl frantically running. The audience does not see that from which she runs; we only experience her visceral panic. Then the screen jumps to the image of her dead body: her leg is broken and bent at a $45^{\circ}$ angle; it hangs over her in a seemingly impossible position, her knee directly over her stomach, the point of her shoe over her chest, the heel reaching up towards the sky. It has caught up with her; no longer mobile, no longer beautiful, she is crooked. I wish you'd learn better before we all totter/into our coffins where there's no straight way to lie crooked. The death of the straightness of youth and beauty births the crooked. 
What if we had learned better? What if instead of haunted we were halted by what follows? What if instead of spooked we let what follows spoil us. Can we see that which haunts as also that which halts? That which spooks as that which spoils? Halts and spoils the flow of neoliberalism? For when one reads a "Dramatic Monologue in the Speaker's Own Voice", who exactly is in search of a horror movie? Whose "womanhood" (read desirability) haunts like an amputated leg? Who has gone untouched? From whom have others glanced away? Is it not the "I" reading such a monologue now in my own voice? The it that follows me, even in its singularity, is also of course the me that is afraid of being followed. Running counter to the eugenics of neoliberalism, a wealth that is time and a beauty that comes in true singularity encourage the touching and desiring of all, regardless of how bent we might be, regardless of how long it might take to stroke us gently open. In this wealthy crip time there is a listening to the cacophony, not merely a frantic taming of the noise. In attending to the monster that therefore I am follows me $\mathrm{e}^{14}$ we might clear room for a slow living that would represent a different kind of assembly than that birthed by the eventive productivity of the multitude.

\section{(Un)commonly unredeemed}

If the horror of disability spreads like that of an STI, then perhaps there is something we can learn from a return to the non-compliant and counter-redemptive quotidian acts embodied by the mark of the sociopath (the mad) as represented in Gary in My Pocket. For instance, a similar counter-redemption can be found in Cvetkovich's Depression: A Public Feeling (2012). Cvetkovich depathologizes and devindividualizes depression. She rejects cure, or what we might call redemption, in favour of what she names "the utopia of ordinary habit" (Cvetkovich, 2012: 154-202). This utopia is inhabited by acts not of salvation but rather of spending time in manners that counter both panic and the frantic attempt to numb depression. In other words, ordinary utopian habits are habits of spending time over saving it. Hence, the concept of the utopia of everyday habit asks us to consider how and with whom we spend the wealth of our time. In her description of a Public Feelings ${ }^{15}$ event in Toronto Cvetkovich (2012: 188) writes, "[it was] a discussion of art and utopia that included a group sing-along of cover songs ranging from Britney Spears's '... Baby One More Time' (in homage to the version sung by Kiki and Herb as much as to Britney herself) to Joni Mitchell's 'The Circle Game' (for Canadian content). As we huddled together in the slightly too close embrace of shag rugsand crocheted afghans, it felt like there was room both to express loneliness and to feel a little less lonely". Cvetkovich has not been redeemed out of her loneliness, but in spending the wealth of her time with others willing to attend to such a time she feels a little less lonely. She is not cured, but neither is Cvetkovich chained to the structures-of time, feeling, life and work-that made her so lonely in the first place.

This is not redemption as much as it is remaining with a difference. At the end of It Follows Jay walks hand in hand with her childhood first kiss Paul, whom she has now slept with and thus we assume she has infected with it. At first glance Jay seems the image of innocence and beauty, her golden locks flowing down onto her white summer dress. But then we feel it, the affect in her eyes: she is exhausted from panicked fleeing and fearful hiding. As Paul and Jay walk, the audience sees a slow-moving "person" following them in the distance. It Follows and this poetics of disability do not offer a happy ending; both refuse to shake the spectre of our own crippness.

At the end of After the Future Berardi acknowledges that proposals such as these often leave his audience with a sense of bitterness. He does not have a happy ending either: "And I don't like to cheat at the game. I don't like empty words of self-reassurance, or rhetoric about the multitude. I prefer to tell the truth, at least, the limited truth as I see it: there is no way out, social civilization is over, the neoliberal precarization of labor and the media dictatorship have destroyed the cultural antibodies that, in the past, made resistance possible. As far as I know" (Berardi, 2011: 158). And yet he persists. It persists. The crip persists. For instance, writing about Miller's poetry Jill Alexander Essbaum acknowledges that, "While [Miller's] poems are often grave and dismal in their imagery, by their tone they are backlit with hope" (Alexander Essbaum et al., 2011: 51). While, as Essbaum notes, Miller's hope may come from her commitment to her Christianity (Alexander Essbaum et al., 2011: 51), I want to offer an alternate theological reading. Perhaps hope backlights the dismal and the grave, because it is through this gravity (a pulling down as opposed to a speeding up) that we might recognize, perhaps to our horror, our own crooked natures. In recognizing that we too are bent, we might be better prepared to wilfully go our own autonomous ways. In other words, perhaps this kind of hope, a hope that comes through and in our brokenness, illuminates a desire for and an embrace of the realization that there is no way to lie straight in the end. For Berardi this hope comes in the very fact that his brain is limited-that while "his knowledge and understanding don't see how any development of the social catastrophe could cultivate social well-being", he also knows that he does not need to know or understand how because "the catastrophe (in the etymology of kata and stopherin) is exactly the point where a new landscape is going to be revealed" (Berardi, 2011: 162). In attending to the catastrophe we hold out faith that we might actually be able to reclaim the wealth of time and the beauty of our singularities. And we might push this faith even farther, asking how we can embrace the crip that follows. We might follow the following where it wills.

The wilfully monstrous need not wander away from all senses of collectivity. Monstrosity might come apart from a risky commonality of productivity on offer by Rieger and Kwok only to come noisily together in what Fred Moten and Stefano Harney name the Undercommons (a marooned community, particularly in the University, already considered to be fugitive invaders-never productive or professional enough). For example, Jack Halberstam notes in the introduction to the Undercommons that "the disordered sounds that we refer to as cacophony will always be cast as 'extramusical,' as Moten puts it, precisely because we hear something in them that reminds us that our desire for harmony is arbitrary and in another world, harmony would sound incomprehensible. Listening to cacophony and noise tells us that there is a wild beyond to the structures we inhabit and that inhabit us" (Moten and Harney, 2013: 7). Halberstam continues, "And when we are called to this other place, the wild beyond, 'beyond the beyond' in Moten and Harney's apt terminology, we have to give ourselves over to a certain kind of craziness" (Moten and Harney, 2013: 7).

We can give ourselves over to this madness, to the ecstasy and depression of a chaotic cacophony murmured by those crip monsters on whose effacement harmony was built. This crazy (depressed, exhausted, inexpressible and unreasonable) we is not a we that will come from a suppression of each singularity's maddening noise into a harmonious battle hymn of a productive multitude, even if the we will wage its own, perhaps slow, war. For this cacophony is the sound of Ahmed's (2014: 184) wilful politics, which "[refuses] to cover over what is missing, a refusal to aspire to be whole". No common battle hymn, but rather "A queer army ... that is not willing to reproduce the whole, an army of unserviceable parts. You can be assembled by what support you refuse to give. A queer army of parts without bodies, as well as bodies without parts, to evoke Audre Lorde's call for an army of one-breasted women" (Ahmed, 2014: 199). This is a call to arms that in its 
monstrous handness is also a refusal. It is a refusal not of life, but of the lives on offer by neoliberalism. It is a refusal that demands and "exalt[s] tenderness, sleep, and ecstasy, the frugality of needs and the pleasure of the senses" (Berardi, 2011: 166).

In other words, I would rather be reclining than redeemed. I would rather be sleeping than saved. I would rather be pleasured than productive.

\section{Notes}

1 Autonomism is a school of thought and action most commonly traced back to the workerist or Operaismo movement in Italy in the 1960s and 1970s (a movement of which Antonio Negri was a part). In general autonomism represents a stance towards capitalist labour in which instead of seeking reform of the system one seeks autonomy from capitalist production. For instance, Franco "Bifo" Berardi, a leading voice in contemporary autonomist thought (and a primary theorist for the constructive work of this essay), has referred to autonomism as "out-onomy", which names the formation of ways of living that get one out of the capitalist economy.

2 SemioCapitalism is a neo-liberal economy in which we are flooded with and dictated by an exhaustive flow of signs without referents.

3 Crip theory is a form of disability studies that does not seek accessibility and acceptance, but rather, similar to queer theory, looks (through the experience of the disabled) to destabilize heteronormative and ableist systems of accessibility and acceptability.

4 By "singular" here, and by "singularity" elsewhere in this essay, I refer not to an individualism, but rather back to the concept of singularity employed by Berardi (2011: 148) (reading Gilles Deleuze's concept of singularity in which individuation [the uniqueness of each singularity is not the same as indvidualism]) in which a singularity resists homoginization while keeping the uniqueness and creative potential of each entity within an assemblage of entities at the fore.

5 My use of "wilful" here and later in this essay refers to Ahmed's work on wilfulnes in Willful Subjects (2014). According to Ahmed (2014: 23), certain forms of living are considered wilful because they "pulse" with a desire directed away from that of the mainstream. They wilfully come apart and wander where they will (Ahmed, 2014: 50).

6 For some examples of such political work, see Weeks's arguments for a dedicated wage and a 30-hour work week in The Problem with Work: Feminism, Marxism, Antiwork Politics, and Postwork Imaginaries (2011).

7 See, for instance, Religion, Politics, and the Earth: The New Materialism (Crockett and Robbins, 2012), as well as essays by Randall Johnson and John Thibdeau in The Future of Continental Philosophy of Religion (Crockett, Putt and Robbins editions, 2014).

8 I get the concept of bodymind from a virtual roundtable on "cripistemologies" convened and edited by Robert McRuer and Merri Lisa Johnson in which Margaret Price (who found the concept of bodymind in the work of Babette Rothschild) uses the term to represent how we cannot talk about mind or brain split from the body (McRuer and Johnson, 2014: 153).

9 See, for example, Slavoj Žižek's work on revolution and his deployment of the work of Badiou that spans across his work; Alain Badiou's Being and Event (2013a), Logics of Worlds: Being and Event II (2013b) and Philosophy and the Event (2013c); Crockett's Deleuze Beyond Badiou (2013) and Radical Political Theology (2011); Robbins's Radical Democracy and Political Theology (2013); the collected volume Theology and the Political: The New Debate (Davis, Milbank and Žižek eds, 2005); and John D Caputo's The Weakness of God: A Theology of the Event (2006).

10 Speeding up change, moving upward might be reworked through slowing things down or moving downward.

11 Shaviro (2015: 1) defines accelerationism as "the argument that the only way out is the way through. In order to overcome globalized neoliberal capitalism, we need to drain it to the dregs, push it to its most extreme point, follow it into its furthest and strangest consequences".

12 While I hope this essay makes clear my doubt that a speed-up to a breaking point is the aesthetic mode most apt for resisting neoliberalism, both Shaviro's accelerationism and Berardi's radical passivity reject ultra-leftist revolutionary politics in favour of alternate embodiments of becoming differently in the world.

13 Negri refers to Imperial Power with a capital P to distinguish it from the generalized force of power.
14 Here I refer (with a différance) to Jacques Derrida's The Animal that Therefore I Am, which more accurately translated from the French would be The Animal that Therefore I Am/I Follow.

15 The Public Feelings Project brings together activists, artists and academics doing critical work in the study of theoretical, historical and artistic materials engaged with political affects and the politics of affect.

\section{References}

Ahmed S (2014) Willful Subjects. Duke University Press: Durham, NC and London.

Alexander Essbaum J (2011) Swimming on concrete: The poetry of Vassar Miller. In: Bartlett J, Black S and Northen M (eds) Beauty is a Verb: The New Poetry of Disability. Cinco Puntos Press: El Paso, TX.

Badiou A (2013a) Being and Event. Contunuum: London, UK.

Badiou A (2013b) Logics of Worlds: Being and Event II. Bloomsbury Academic: London, UK

Badiou A (2013c) Philosophy and the Event. Polity Press: Cambridge, UK.

Berardi F (2011) After the Future. AK Press: Edinburgh, UK; Oakland, CA; Baltimore, MD.

Berardi F (2009) The Soul at Work: From Alienation to Autonomy. Semiotext(e): Los Angeles, CA.

Berlant L (2011) Cruel Optimism. Duke University Press: Durham, NC and London. Caputo JD (2006) The Weakness of God: A Theology of the Event. Indiana University Press: Bloomington, IN.

Casarino C and Negri A (2008) In Praise of the Common: A Conversation on Philosophy and Politics. University of Minnesota Press: Minneapolis, MN.

Crockett C (2011) Radical Political Theology: Religion and Politics after Liberalism. Columbia University Press: New York.

Crockett C (2013) Deleuze beyond Badiou. Columbia University Press: New York

Crockett C, Putt BK and Robins JW (2014) The Future of Continental Philosophy of Religion. Indiana University Press: Bloomington, IN.

Crockett C and Robbins J (2012) Religion, Politics, and the Earth: The New Materialism. Palgrave Macmillan: New York.

Cvetkovich A (2012) Depression a Public Feeling. Duke University Press: Durham, $\mathrm{NC}$ and London.

Davis C, Milbank J and Žižek S (2005) Theology and the Political: The New Debate. Duke University Press: Durham, NC.

Deleuze G and Guattari F (1994) What is Philosophy? Verso: New York, NY and London.

Foucault M (2006) History of Madness. Routledge: Abingdon, Oxon, UK; New York.

Foucault M (1978) The History of Sexuality: An Introduction, Volume I. Pantheon Books: New York, NY.

Goodchild P (2009) Theology of Money. Duke University Press: Durham, NC and London.

Hardt M and Negri A (2005) Multitude: War and Democracy in the Age of Empire. Penguin Books: New York, NY.

It Follows. (2015) Film. Directed by David Robert Mitchell. [DVD] US: Dimension Films.

Love H (2007) Feeling Backward: Loss and the Politics of Queer History. Harvard University Press: Cambridge, MA.

McRuer R (2006) Crip Theory: Cultural Signes of Queerness and Disability. New York University Press: New York and London.

McRuer R and Johnson M L (eds) (2014) Proliferating cripistemologies: A virtual roundtable. Journal of Literary \& Cultural Disability Studies; 8 (2): 149-169.

McRuer R, Mollow A (2012) Introduction. In: McRuer R and Mollow A. (eds) Sex and Disability. Duke University Press: Durham, NC and London.

Moten F and Harney S (2013) The Undercommons: Fugitive Planning and Black Study. Autonomedia Press: New York.

Riger J and Kwok P (2012) Occupy Religion: Theology of the Multitude. Rowan and Littlefield Publishers: Lanham, MD; Plymouth: UK.

Robbins J (2013) Radical Democracy and Political Theology. Columbia University Press: New York.

Shaviro S (2015) No Speed Limit: Three Essays on Accelerationism. University of Minnesota Press: Minneapolis, MN

Schweik S (2011) The voice of "reason". In: Bartlett J, Black S and Northen M (eds) Beauty is a Verb: The New Poetry of Disability. Cinco Puntos Press: El Paso, TX

Weeks K (2011) The Problem with Work: Feminism, Marxism, Antiwork Politics and Postwork Imaginaries. Duke University Press: Durham, NC and London.

Zižek S (2006) The Parallax View. Massachusetts Institute of Technology: Cambridge, MA. 


\section{Data Availability}

Data sharing not applicable to this article as no datasets were generated or analysed during the current study.

\section{Additional Information}

Competing interests: The author declares no competing financial interests.

Reprints and permission information is available at http://www.palgrave-journals.com/ pal/authors/rights_and_permissions.html
How to cite this article: Bray K (2015) The monstrosity of the multitude: unredeeming radical theology. Palgrave Communications. 1:15030 doi: 10.1057/palcomms.2015.30.

(c) (i) This work is licensed under a Creative Commons Attribution 3.0 ${ }_{\mathrm{BY}}$ International License. The images or other third party material in this article are included in the article's Creative Commons license, unless indicated otherwise in the credit line; if the material is not included under the Creative Commons license, users will need to obtain permission from the license holder to reproduce the material. To view a copy of this license, visit http://creativecommons.org/licenses/by/3.0/ 